\title{
Severe colchicine intoxication after self-administration of colchicine concomitantly with loxoprofen
}

\author{
Akinori Yamazaki · Hiroshi Iranami • \\ Koichi Nishikawa
}

Received: 14 September 2012/ Accepted: 18 November 2012/Published online: 8 December 2012

(C) The Author(s) 2012. This article is published with open access at Springerlink.com

Keywords Colchicine $\cdot$ Intoxication · Loxoprofen · Multiple organ failure

To the Editor:

We describe a patient with gout who developed serious multiple system organ failure after the self-administration of colchicine together with loxoprofen.

A 38-year-old male (height $175 \mathrm{~cm}$, weight $75 \mathrm{~kg}$ ) with no pre-existing diseases had been prescribed colchicine (1 tablet) together with loxoprofen (1 tablet) for gout attack by his family physician. Following the severest pain attack at his toe that he had ever experienced, he self-administered 30 tablets of colchicine $(15 \mathrm{mg})$ together with ten loxoprofen tablets $(600 \mathrm{mg})$ within a 6 -h period. His pain subsided $3 \mathrm{~h}$ after the last intake of the tablets, but he presented to our medical center because of gastrointestinal symptoms including nausea, vomiting, diarrhea, and hematemesis.

\footnotetext{
A. Yamazaki · H. Iranami · K. Nishikawa

Department of Anesthesiology, Wakayama Medical

University, 811-1 Kimiidera, Wakayama City,

Wakayama 641-0012, Japan

H. Iranami ( $\square)$

Department of Anesthesiology, Japanese Red

Cross Society Wakayama Medical Center,

4-20 Komatsubara-dori, Wakayama,

Wakayama 640-8269, Japan

e-mail: runbeerclub@yahoo.co.jp
}

The patient developed acute renal failure on the second hospital day, and on the third hospital day, he entered a delirious state, with thrombocytopenia, respiratory failure, and severe hypotension. Granulocyte colony stimulating factor $(250 \mu \mathrm{g} /$ day $)$ was administered for his severe pancytopenia on hospital days 4-7. On hospital day 9, his urine output began to increase, and on hospital day 18 , the patient had been successfully weaned from the mechanical ventilation. He was discharged from the hospital on hospital day 26. All of the blood and laboratory parameters on hospital day 25 were within the normal ranges, but alopecia, muscle weakness (MMT 4/5), disappeared ankle tendon reflex, reduced evoked potentials of peripheral nerves, including the median, ulnar, and tibial nerves, remained (Table 1).

The first symptom of this patient was that of gastrointestinal tract, followed by the subsequent multiple organ failure, including the cardiovascular, renal, hepatic, respiratory, myeloproliferative, central and peripheral nervous systems, which sequentially developed as precisely described in Stapczynski et al.'s review [1]. The severity of our patient's colchicine intoxication correlated well to the intake doses; i.e., an oral intake of $<0.5 \mathrm{mg} / \mathrm{kg}$ only exerts gastrointestinal tract symptoms, that from 0.5 to $0.8 \mathrm{mg} / \mathrm{kg}$ results in multiple organ failure, and an oral intake of $>0.8 \mathrm{mg} / \mathrm{kg}$ can be lethal [2]. The total intake of colchicine in this patient was $15 \mathrm{mg}(0.2 \mathrm{mg} / \mathrm{kg})$, and he did not have any pre-existing diseases. The co-administration of macrolides promotes colchicine's toxicities [3, 4], but, to our knowledge, there has been only one report of colchicine toxicity in association with indomethacin [5]. Colchicine, anti-inflammatory drugs (NSAIDs), and corticosteroids are commonly used to treat gout. It would appear that a possible interaction between colchicine and NSAIDs could cause a fatal complication. 
Table 1 Blood, serum, and coagulation data during the hospitalization of this patient

\begin{tabular}{|c|c|c|c|c|c|c|c|c|c|c|}
\hline Blood, serum, and coagulation data & Normal range & Day 1 & Day 2 & Day 3 & Day 4 & Day 5 & Day 6 & Day 7 & Day 18 & Day 25 \\
\hline White blood cells $(/ \mathrm{ml})$ & $4000-7000$ & 29700 & 19500 & 6000 & 900 & 400 & 900 & 3500 & 11400 & 8400 \\
\hline Hemoglobin $(\mathrm{g} / \mathrm{dl})$ & $14.0-18.0$ & 17.6 & 16.1 & 14.4 & 11.0 & 9.8 & 7.9 & 7.3 & 8.6 & 8.7 \\
\hline Hematocrit $(\%)$ & $40.0-52.0$ & 51.7 & 47.8 & 42.5 & 31.7 & 27.3 & 22.6 & 20.5 & 24.8 & 25.7 \\
\hline Platelets $(/ \mathrm{ml})$ & $15.0-40.0$ & 26.7 & 11.0 & 2.7 & 2.3 & 1.5 & 1.3 & 2.0 & 10.2 & 28.1 \\
\hline Prothrombin time $(\%)$ & $85-120$ & 36 & 45 & 76 & 87 & 87 & 93 & 95 & 77 & \\
\hline Prothrombin time (INR) & & 2.3 & 1.89 & 1.21 & 1.10 & 1.10 & 1.05 & 1.03 & 1.20 & \\
\hline Activated partial thrombin time (s) & $28-40$ & 56.4 & 70.3 & 52.0 & 47.9 & 38.7 & 41.7 & 40.6 & 37.6 & \\
\hline Fibrinogen (mg/dl) & $200-400$ & 374 & 598 & 799 & 766 & 822 & 692 & 586 & 396 & \\
\hline Alkaline phosphokinase (U/l) & $104-338$ & 2579 & 2714 & 1323 & 565 & 481 & 359 & 327 & 179 & 229 \\
\hline Aspartate amino transferase (U/l) & $5-40$ & 375 & 405 & 344 & 210 & 188 & 177 & 115 & 80 & 29 \\
\hline Alanine amino transferase (U/l) & $5-35$ & 52 & 49 & 42 & 44 & 77 & 100 & 79 & 44 & 31 \\
\hline Lactate dehydrogenase (U/1) & $50-400$ & 12250 & 13630 & 10740 & 4850 & 2083 & 1115 & 835 & 1290 & 506 \\
\hline Creatinine phosphokinase (U/l) & 20-190 & 1058 & 1518 & 2871 & 1937 & 929 & 283 & 383 & 799 & 36 \\
\hline Blood urea nitrogen $(\mathrm{mg} / \mathrm{dl})$ & $8-20$ & 42 & 41 & 33 & 28 & 25 & 30 & 32 & 80 & 29 \\
\hline Creatinine $(\mathrm{mg} / \mathrm{dl})$ & $0.6-1.5$ & 4.4 & 3.8 & 3.5 & 2.7 & 2.8 & 2.6 & 2.2 & 2.8 & 0.9 \\
\hline C-reactive protein $(\mathrm{mg} / \mathrm{dl})$ & -0.3 & 35.51 & 53.88 & 54.25 & 26.85 & 25.51 & 19.05 & 21.05 & 2.72 & 0.95 \\
\hline
\end{tabular}

Open Access This article is distributed under the terms of the Creative Commons Attribution License which permits any use, distribution, and reproduction in any medium, provided the original author(s) and the source are credited.

\section{References}

1. Stapczynski JS, Rothstein RJ, Gaye WA, Niemann JT. Colchicine overdose: report of two cases and review of the literature. Ann Emerg Med. 1981;10:364-9.

2. Brvar M, Ploj T, Kozelj G, Mozina M, Noc M, Bunc M. Case report: fatal poisoning with Colchicum autumnale. Crit Care. 2004;8:R56-9.
3. Caraco Y, Putterman C, Rahamimov R, Ben-Chetrit E. Acute colchicine intoxication-possible role of erythromycin administration. J Rheumatol. 1992;19:494-6.

4. Rollot F, Pajot O, Chauvelot-Moachon L, Nazal EM, Kelaidi C, Blanche P. Acute colchicine intoxication during clarithromycin administration. Ann Pharmacother. 2004;38:2074-7.

5. Borrás-Blasco J, Enriquez R, Sirvent AE, Amoros F, NavarroRuiz A, Reyes A. Acute renal failure associated with an accidental overdose of colchicine. Int J Clin Pharmacol Ther. 2005;43:480-4. 